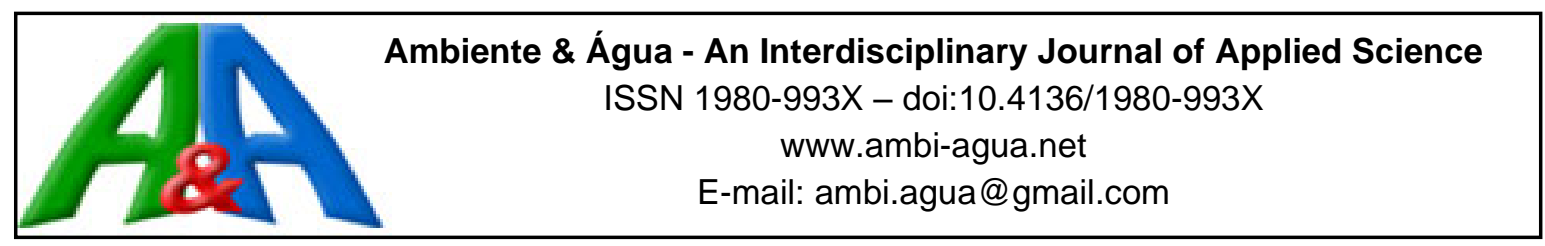

\title{
Membrane bioreactor for mall wastewater treatment
}

\author{
ARTICLES doi:10.4136/ambi-agua.2489
}

Received: 01 Nov. 2019; Accepted: 06 Feb. 2020

\section{Everton Luis Butzen $^{1}{ }^{(D}$; Gabriel Capellari Santos ${ }^{1}$; ; Sandrini Slongo Fortuna1 ${ }^{1 D}$; Vandré Barbosa Brião ${ }^{2 *(i D)}$}

\begin{abstract}
${ }^{1}$ Faculdade de Engenharia e Arquitetura. Programa de Pós Graduação em Engenharia Civil e Ambiental. Universidade de Passo Fundo (UPF), Rodovia BR 285, S/N, CEP: 99052-900, Passo Fundo, RS, Brazil. E-mail: everbutzen@gmail.com, gabriel_capellari@hotmail.com, sandrinislongo@outlook.com ${ }^{2}$ Faculdade de Engenharia e Arquitetura. Universidade de Passo Fundo (UPF), Rodovia BR 285, km 292, n 7, CEP: 99052-900, Passo Fundo, RS, Brazil

*Corresponding author. E-mail: vandre@upf.br
\end{abstract}

\begin{abstract}
Malls concentrate a large number of people in a relatively small area, and thus generate concentrated urban wastewater. This study evaluated the performance of a membrane bioreactor (MBR) as an alternative for the treatment of mall wastewater. Wastewater samples without any previous treatment were collected from a medium-size mall and showed a high chemical oxygen demand (COD) near 2,000 $\mathrm{mg} \mathrm{L}^{-1}$. The MBR operated with a constant pressure of 40 $\mathrm{kPa}$ during 60 days with a sludge age of 30 days. Concentration of biomass was $3,738 \pm 930 \mathrm{mg}$ $\mathrm{L}^{-1}$ and average permeate flux was $7.0 \mathrm{~L} \mathrm{~h}^{-1} \mathrm{~m}^{-2}$. The MBR was able to remove $91.2 \%$ and $97.2 \%$ of color and turbidity, respectively. Furthermore, COD removal was approximately $90 \%$ and biochemical oxygen demand (BOD) $88 \%$. In addition, the MBR produced a phosphorus removal near $50 \%$, and for nitrogen, $80 \%$. The MBR system proved to be an efficient process for the removal of the pollutants, remaining stable even with the oscillation of the characteristics of the raw sewage, presenting great potential for application in the treatment of sewage from malls and effluents with high organic loads.
\end{abstract}

Keywords: activated sludge, effluent, MBR, sewage, ultrafiltration.

\section{Bioreator de membrana para o tratamento de águas residuais de shopping centers}

\section{RESUMO}

Os shoppings têm um alto movimento de pessoas em locais compactos e, assim, geram águas residuais urbanas concentradas. Este estudo avaliou o desempenho do biorreator de membrana (MBR) como uma alternativa para o tratamento de águas residuais de shopping centers. Amostras de águas residuais sem tratamento prévio foram coletadas em um shopping de tamanho médio e apresentaram alta demanda química de oxigênio (DQO) próxima a 2.000 mg L-1. O MBR operou com pressão constante de $40 \mathrm{kPa}$ durante 60 dias com idade do lodo de 30 dias. A concentração de biomassa foi de $3.738 \pm 930 \mathrm{mg} \mathrm{L}-1$ e o fluxo médio de permeado foi de 7,0 L h-1 m-2. A MBR conseguiu remover 91,2\% e 97,2\% da cor e turbidez, respectivamente. Além disso, a DQO foi removida em aproximadamente $90 \%$ e a demanda bioquímica de oxigênio (DBO) em $88 \%$. Além disso, o MBR produziu uma remoção de fósforo 
perto de $50 \%$ e para o nitrogênio esse valor foi de $80 \%$. O sistema MBR demonstrou ser um processo eficiente na remoção dos poluentes mantendo-se estável mesmo com a oscilação das características do esgoto bruto, apresentando grande potencial de aplicação no tratamento de esgoto de shopping centers e efluentes com altas cargas orgânicas.

Palavras-chave: efluente, esgoto, lodo ativado, MBR, ultrafiltração.

\section{INTRODUCTION}

Malls are densely occupied urban structures. Their infrastructure includes water supply, sanitation and storm drainage, and thus generates effluents (e.g. from toilets and restaurants) with higher organic load than domestic wastewater.

The compactness of malls makes the treatment of sewage difficult, since in general this treatment occupies large areas located in the middle of cities, lacking efficient solutions for an adequate environmental balance. The treatment of sewage from malls can create a bottleneck in the mall's operation.

The increase of sewage generation has been overloading existing municipal sewage treatment plants, and in many cases there is no room available for plant expansion (Neoh et al., 2016). Restrictions of physical space for new systems or expansion of existing systems, the low performance of conventional systems, the impossibility of interconnections in the collection networks and overloads in the treatment plants can make it difficult to treat mall sewage. In addition to containing pathogens, microorganisms and toxic wastes, raw sewage may contain high concentrations of nitrogen and phosphorus, and discharges without proper treatment may enhance water eutrophication (Belli et al., 2014).

Activated sludge is a usual process for the treatment of sewage and can be useful for treatment of mall wastewater because it can remove high organic load and nitrogen and can reduce the risk of pathogens in the effluent. However, these treatments can require a large physical space and have high operating costs. Furthermore, secondary settling has limitations. It can present low efficiency and sedimentation problems when hydraulic detention time is low; there can be small biological flakes with open structures or malformation, and the occurrence of sludge bulking can also lead to poor operation (Subtil et al., 2013). The result is a treated effluent with suspended and colloidal material, increasing BOD and suspended solids due to cellular material in the water.

Membrane bioreactors (MBR) combine the activated sludge process with solid/liquid separation through membranes, replacing the sedimentation stage of conventional systems (Rodríguez-Hernández et al., 2014). MBRs show a great advance in wastewater treatment. In addition, the effluent treatment is considered to be superior to conventional biological systems as it produces a better quality permeate (Komesli et al., 2015).

The main characteristics of the MBR are the large capacity of retention of biological material in the membranes, operation with large biomass load with longer cell detention time, and the removal of bacteria and viruses without the incorporation of chemical agents (Villain and Marrot, 2013; Komesli et al., 2015, Maqbool et al., 2014). They are flexible and compact systems that require little area for installation, and they have been applied on a large scale worldwide and have been constantly optimized and adapted to new configurations that seek to improve their performance (Huang and Lee, 2015). Membrane bioreactors can be easily adapted to different operating cycles, with the incorporation of anaerobic / anoxic periods, which can operate with high efficiency in the removal of organic matter and nutrients with simultaneous nitrification and denitrification conditions (Barbosa et al., 2016; Belli et al., 2014; Capodici et al., 2015).

The process with MBR has been researched for the treatment of effluents in several sectors: 
Keskes et al. (2012) used MBR for the wastewater of slaughterhouse effluent; Belli et al. (2014) and Capodici et al. (2015) treated municipal wastewater; and Nguyen et al. (2016) for wastewater from hospitals. Praneeth et al. (2014) used a submerged MBR for treatment of dairy wastewater. Subtil et al. (2014) compared two configurations of MBR for the treatment of domestic wastewater. However, malls can generate high volumes of wastewater in restricted areas. Thus, there is a need to evolve the study to evaluate the real capacity of MBR to be applied in the malls. Furthermore, the stability of the systems and the determination of optimal operating conditions with the control of membrane clogging remain major challenges for MBRs (Krzeminski et al., 2017), and studies should be expanded to increase knowledge on the subject.

This study evaluated the feasibility of the membrane bioreactor system for the treatment of mall effluent, analyzing physical and chemical parameters of the raw sewage and permeate, treatment efficiency and their stability.

\section{MATERIAL AND METHODS}

The mall where the samples of the wastewater were collected is located at University of Passo Fundo (Brazil). The mall houses different commercial establishments, such as a drug store, bookstore, bank branch, toilets, as well as a food court with seven restaurants, snack bars, ice cream shop and coffee shop. The sampling was carried out in the sewer drain (GPS position: -28.232340, -52.382619) located near the building, without any preliminary treatment, over a period of 60 days between August and September. The characterization of the wastewater is shown in Table 1.

Table 1. Physic chemical characteristics of the mall sewage and permeate, and the removal efficiency of MBR during a 60-day treatment period.

\begin{tabular}{|c|c|c|c|}
\hline Parameter & Raw wastewater & Permeate & Removal \\
\hline Color (Hazen) & $580.10 \pm 280.27$ & $51.05 \pm 11.08$ & $91.20 \%$ \\
\hline Turbidity (NTU) & $680.10 \pm 336.01$ & $19.00 \pm 9.72$ & $97.20 \%$ \\
\hline $\mathrm{COD}\left(\mathrm{mg} \mathrm{L}^{-1}\right)$ & $1.849 .90 \pm 174.28$ & $189.44 \pm 30.22$ & $89.76 \%$ \\
\hline $\mathrm{BOD}_{5}\left(\mathrm{mg} \mathrm{L}^{-1}\right)$ & $991.67 \pm 352.81$ & $121.22 \pm 80.17$ & $87.78 \%$ \\
\hline Phosphorus (mg L-1) & $25.30 \pm 17.64$ & $12.85 \pm 8.12$ & $49.22 \%$ \\
\hline Kjeldahl nitrogen $\left(\mathrm{mg} \mathrm{L}^{-1}\right)$ & $32.60 \pm 17.18$ & $5.02 \pm 3.56$ & $84.61 \%$ \\
\hline Ammonium nitrogen $\left(\mathrm{mg} \mathrm{L}^{-1}\right)$ & $15.15 \pm 9.98$ & $2.92 \pm 1.88$ & $80.75 \%$ \\
\hline Nitrites $\left(\mathrm{mg} \mathrm{L}^{-1}\right)$ & $0.65 \pm 0.15$ & $1.65 \pm 0.45$ & - \\
\hline Nitrates $\left(\mathrm{mg} \mathrm{L}^{-1}\right)$ & $1.51 \pm 0.45$ & $4.64 \pm 3.15$ & - \\
\hline
\end{tabular}

The schematic of the experimental unit is shown in Figure 1. The equipment was supplied by PAM Membranes (Rio de Janeiro - Brazil). Samples were stored in a buffer tank, in which a peristaltic pump fed the MBR (6 liter volume). A suction pump (diaphragm) connected to the submerged membrane module produces vacuum inside the membranes, removing permeate (treated effluent). This same pump allows the inversion of the flow, performing the backwashes. Aeration was supplied by a compressor, injecting air at a rate of $4 \mathrm{~L} \mathrm{~min}^{-1}$, measured by a rotameter and maintaining dissolved oxygen (OD) in the range of 3-4 $\mathrm{mg} \mathrm{L}^{-1}$ (analyzed by a digital oximeter). There was a control panel connected to a computer for controlling the operation/backwash cycles, as well as for receiving and storing the MBR information. Level sensors into the permeate tank controlled the purge of permeate by opening a solenoid valve.

The membranes used were of hollow fiber ultrafiltration of polyvinylidene supplied by PAM - Selective Membranes. The total length was $0.25 \mathrm{~m}$, the external diameter of the module was $0.075 \mathrm{~m}$, with a filtration area of $0.22 \mathrm{~m}^{2}$ and molar weight of cut-off $50 \mathrm{kDa}$. 


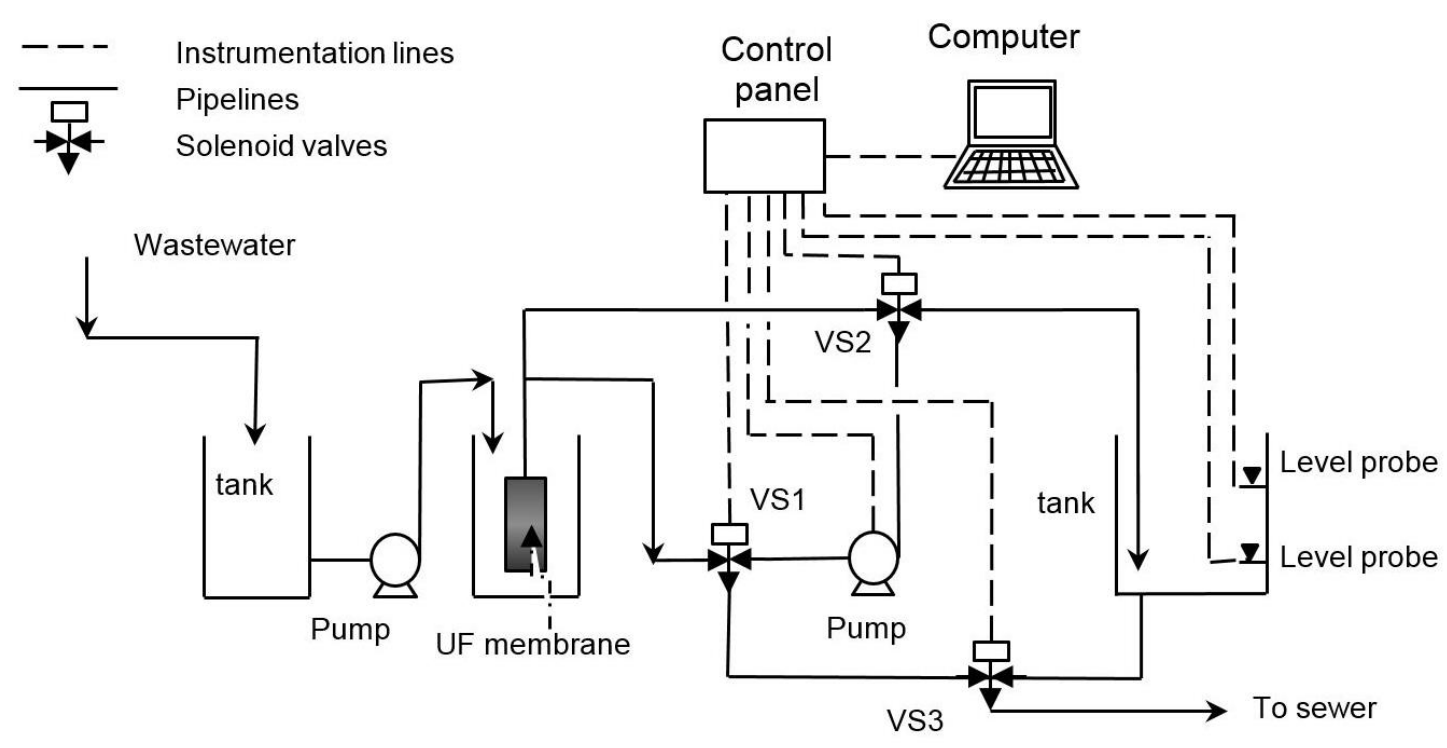

Figure 1. Experimental diagram of the MBR used for the treatment of mall wastewater.

The experimental unit worked for 60 days, keeping the sludge age at 30 days by sludge discharging. The operating cycle was 4 hours of permeation and 30 seconds of backwash. Constant pressure of $40 \mathrm{kPa}$ was used. The hydraulic residence time (HRT) oscillated according to the membrane sealing process, reaching a mean of $4.06 \mathrm{~h} \pm 1.00 \mathrm{~h}$.

The bioreactor was inoculated with sludge from an activated sludge system of a dairy industry, previously acclimatized for 30 days. The total suspended solids concentration (TSS) was $3,000 \mathrm{mg} \mathrm{L}^{-1}$ and during the operation it presented a mean concentration of $3,738 \pm 930 \mathrm{mg}$ $\mathrm{L}^{-1}$. The average $\mathrm{pH}$ was $7.59 \pm 0.51$ and the $\mathrm{F} / \mathrm{M}$ ratio (Food/Microorganism) was measured by $3.33 \mathrm{~d}^{-1} \pm 1.43 \mathrm{~d}^{-1}$ (measured by COD). Over time, permeate flux was recorded.

Samples of raw and treated (permeate) sewage were collected and analyzed for color, turbidity, $\mathrm{COD}, \mathrm{BOD}_{5}$, total phosphorus, total and ammonium nitrogen, nitrites and nitrates. The procedures follow the Standard Methods for the Examination of Water and Wastewater (APHA et al., 2005).

\section{RESULTS AND DISCUSSION}

Table 1 shows the characteristics of the raw wastewater and permeate during the MBR operation, as well as the average removal of the system. Note that the sewage has higher concentration than traditional domestic sewage, which has approximately $300 \mathrm{mg} \mathrm{L}^{-1}$ of BOD, lacking studies for its proper treatment.

The MBR system showed high color removal and turbidity reduction, with an average removal of $91.2 \%$ and $97.2 \%$, respectively. Bani-Melhem et al. (2015) used the MBR system with submerged UF membrane for the treatment of gray water and obtained removal similar to our work (95.20\% for color removal and $96.30 \%$ for turbidity). Removal efficiency and stability were mainly attributed to the physical separation of membranes, retaining suspended and colloidal solids. The color and turbidity removal of the MBR is shown in Figure 2.

The color quality of the permeate as much as the color removal of turbidity remained stable throughout the operation, as can be observed in Figure 2, regardless of the variations in a broad range of the raw sewage characteristics. Note that the color ranged between $~ 100$ NTU and 1100 NTU. In general, malls discharge the treated effluent into the public sewage network, and turbidity is used to determine a surcharge to the mall establishment. Thus, keeping turbidity low is also important from an economic perspective. 


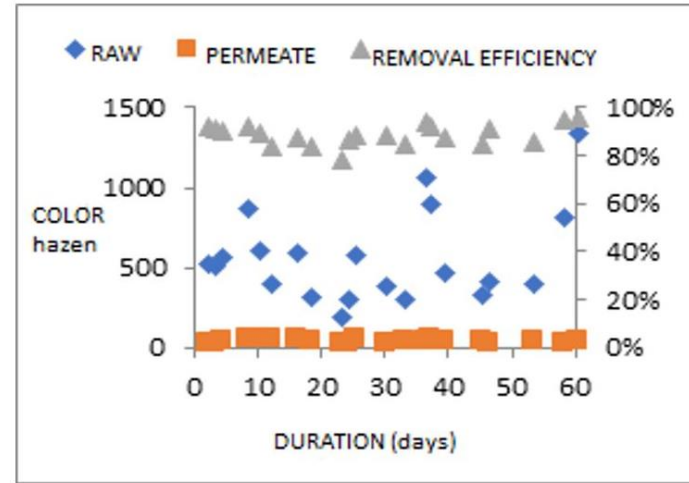

(a)

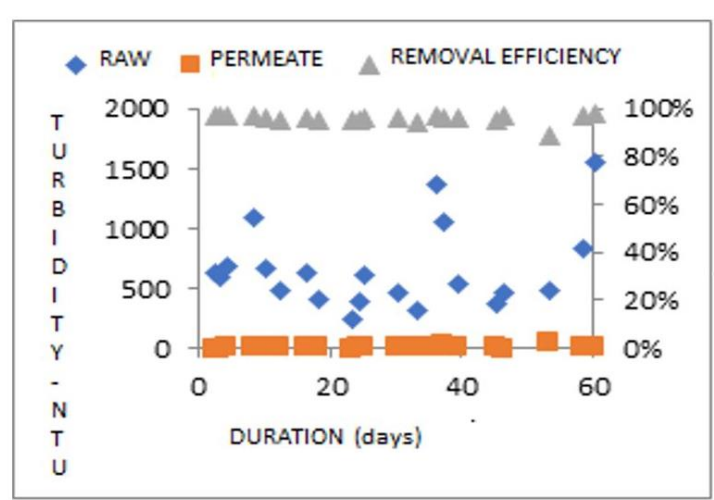

(b)

Figure 2. Color removal (a) and turbidity reduction (b) by the MBR treating mall wastewater.

The concentration of COD of the raw sewage and permeate from the MBR are presented in Figure 3. The MBR achieved an average COD removal of $89.76 \%$, adjusting the COD of permeate below $225 \mathrm{mg} \mathrm{L}^{-1}$. Note that we used a high $\mathrm{F} / \mathrm{M}\left(\sim 3.3 \mathrm{~d}^{-1}\right)$ in a range near that which would produce flocculent sludge, but the membrane was capable of removing the SS and colloidal matter in such a way that the effluent was free of cellular material. The SS concentration is variable according to the load fed to the MBR. For example, treating domestic sewage, Maestri (2007) showed that an MBR is capable of removing $88 \%$ of COD, operating with a concentration of SS between 1,000 and 2,220 mg L $\mathrm{m}^{-1}$ but the wastewater was low in SS concentration. On the other hand, Maqbool et al. (2014) and Komesli et al. (2015) obtained better results, with efficiency varying from $93.3 \%$ to $95.1 \%$, but with SS between $11,000 \mathrm{mg}$ $\mathrm{L}^{-1}$ and $12,000 \mathrm{mg} \mathrm{L}^{-1}$ using synthetic effluent and urban wastewater. However, the synthetic wastewater does not have any inhibitors, such as disinfectants or other constituents of real wastewater. Furthermore, we tried augmenting the concentration of SS into the bioreactor, but the system did not raise beyond $6,000 \mathrm{mg} \mathrm{L}^{-1}$. Thus, we attributed this efficiency mainly to concentration of SS in the bioreactor $\left(3,738 \mathrm{mg} \mathrm{L}^{-1} \pm 930 \mathrm{mg} \mathrm{L}^{-1}\right)$, which can be considered low for a MBR. However, the effluent is free of suspended solids and low in turbidity and color, and could perhaps be a candidate for a post-treatment for reclamation for non-drinking uses. In fact, reuse of domestic wastewater was the main focus of Subtil et al. (2013), where the effluent treated by MBR showed COD, turbidity and color of $24 \mathrm{mg} \mathrm{L}^{-1}, 0.29 \mathrm{NTU}$ and $25 \mathrm{uC}$, respectively. However, the COD of raw the wastewater was only one half that of the mall wastewater (approximately of $1,000 \mathrm{mg} \mathrm{L}^{-1}$ ).

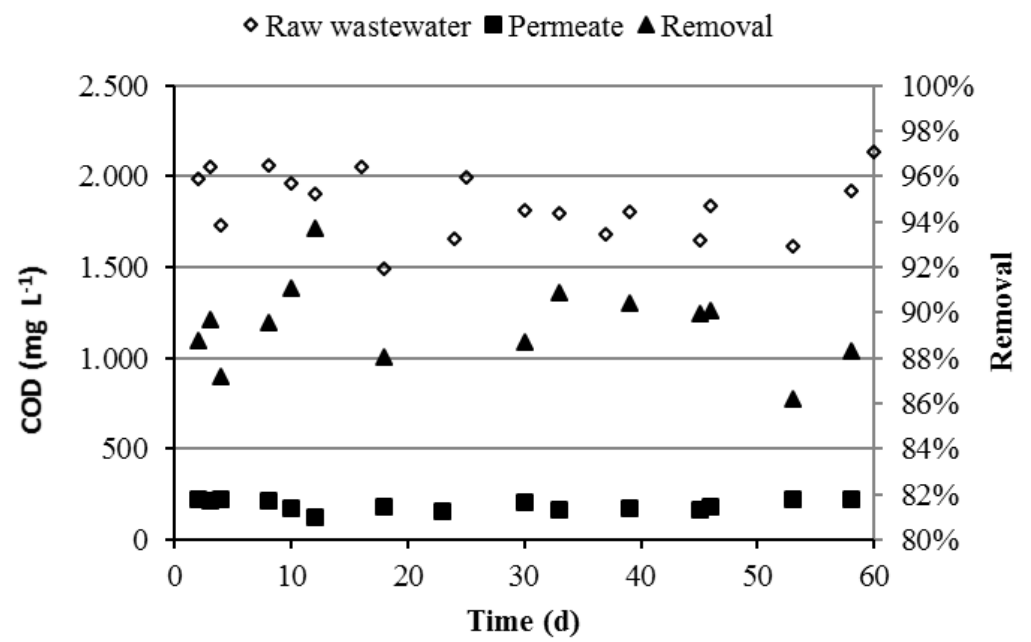

Figure 3. Removal of COD in the MBR by treating mall sewage. 
The COD in the permeate during the MBR operation remained stable with a mean of 189.4 $\mathrm{mg} \mathrm{L}^{-1} \pm 30.2 \mathrm{mg} \mathrm{L}^{-1}$, even with the variations of organic load presented by the raw sewage in Figure 3. Subtil et al. (2013) suggested that COD in the permeate is attributable mainly to the non-biodegradable and non-transformed soluble organic matter that has passed through the physical barrier of the membrane. We used a high organic load, and maybe an overload on activated sludge, and no further degradation of the organic matter was possible. Furthermore, note that a low HRT was enough to reach a COD removal of approximately $90 \%$.

The BOD removal reached an efficiency of $87.78 \%$. Rodríguez-Hernández et al. (2014) achieved $96 \%$ BOD removal efficiency, attributing the high organic removal efficiency of the MBR to the highest concentration or biomass activity into bioreactor. However, RodríguezHernández et al. (2014) studied municipal wastewater with low COD (377 mg L $\left.\mathrm{m}^{-1}\right)$, and the sewage of the mall of our study has higher organic load than the general values of domestic sewage (approximately $300 \mathrm{mg} \mathrm{L}^{-1}$ of BOD).

The efficiency of removal of COD and BOD is directly related to the characteristics of the MBR biomass, besides the capacity of retention of solids in suspension and colloidal substances by the membrane. The operation of MBR with high concentrations of SST in the bioreactor can promote better removal of organic matter from the raw sewage, producing a better permeate.

Figure 4 shows the phosphorus concentrations of raw and treated sewage and the removal of this parameter by MBR. The concentration of phosphorus in the raw sewage was $25.3 \mathrm{mg} \mathrm{L}^{-}$ ${ }^{1} \pm 17.6 \mathrm{mg} \mathrm{L}^{-1}$ and the permeate $12.85 \pm 8.12 \mathrm{mg} \mathrm{L}^{-1}$ (removal of $49.22 \%$ ). This removal is higher than the result of Barbosa et al. (2016), which obtained an efficiency of $33 \%$ for phosphorus. In addition, Rodríguez-Hernández et al. (2014) showed a removal in a range of $37 \%$ and $42 \%$ of phosphorus, for municipal wastewater treated by an MBR, and the removal was attributed to the nutritional need of the microorganisms, disregarding the removal by the phosphorus-accumulating organisms (OAPs) due to the low organic load applied and the high age of the sludge. Furthermore, low F/M rates were responsible for low removals of total phosphorus (20\% to 29\%) in the work developed by Nguyen et al. (2016). Maqbool et al. (2014) reported that the low $4 \mathrm{~h}$ of HRT, associated with the rapid growth of microorganisms was responsible for the typical removal of $41.3 \%$ to $48.2 \%$ achieved in their work. The removal of our work is possibly associated with the combination of all elements: the age of the sludge was around 30 days, a high organic load was applied $\left(\mathrm{F} / \mathrm{M}=3.33 \mathrm{~d}^{-1}\right)$ and the HRT was low (4.18 $\mathrm{h}$ ). This creates a combination where phosphorus is assimilated by microorganisms, and microorganisms are retained by the membrane. We also believed that the presence of phosphates adsorbed on the suspended material and the colloidal substances retained in the membrane have contributed to the excellent performance obtained.

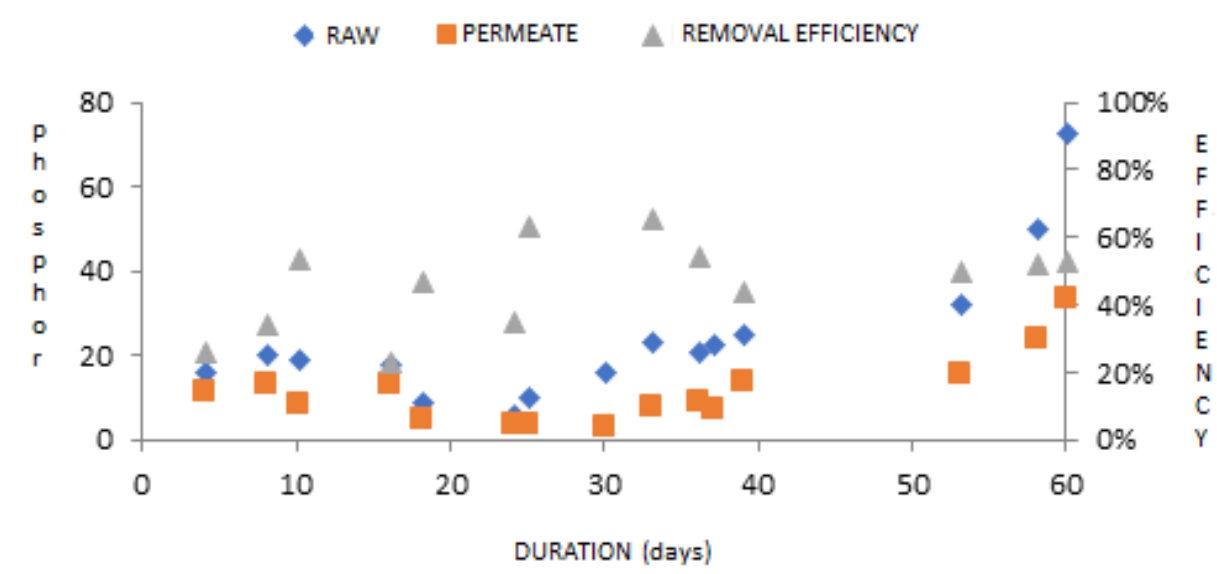

Figure 4. Removal and concentration of phosphorus in raw sewage of the mall and in the permeate treated by the MBR. 
The introduction of anoxic cycle to MBR can improve the removal of phosphorus. Han et al. (2005) operated an MBR to in the intermittent aeration cycles (non-aeration mix feed, aeration, non-aeration phase, aeration filtration) and the removal of phosphorus was up to 72\%. Kellner (2014) and Belli et al. (2014) operated a MBR in sequential batches and an achieved an average efficiency of $70 \%$, which reached $74 \%$ efficiency, assigning the available organic matter to microorganisms with determinants for the large biological removal of phosphorus. However, even without the anoxic cycle of our experiments, the MBR achieved a removal similar to those of usual activated sludge processes.

In regard to nitrogen removal (Figure 5), the raw sewage fed to the MBR presented an average concentration of $32.60 \mathrm{mg} \mathrm{L}^{-1}$ (standard deviation of $17.18 \mathrm{mg} \mathrm{L}^{-1}$ ) and permeate was $5.02 \mathrm{mg} \mathrm{L}^{-1}$. The removal of nitrogen remained in the range of $80 \%$ to $90 \%$ for nearly the entire period of MBR operation, but this value can oscillate over a wide range. For example, Barbosa et al. (2016) performed experiments under constant aeration and a sludge age of 3 days, and a removal efficiency of $81 \%$ was achieved. Capodici et al. (2015) observed removal of nitrogen similar to our work (55\% to 76\%). However, our MBR worked with a low HRT (4 h), whilst Subtil et al. (2014) and Rodriguez-Hernandez et al. (2014) operated the MBR with an HRT of 10 to achieve similar removal of nitrogen (near 80\%). Therefore, sewage quality and operational conditions are important and provide different rates of nitrogen removal.

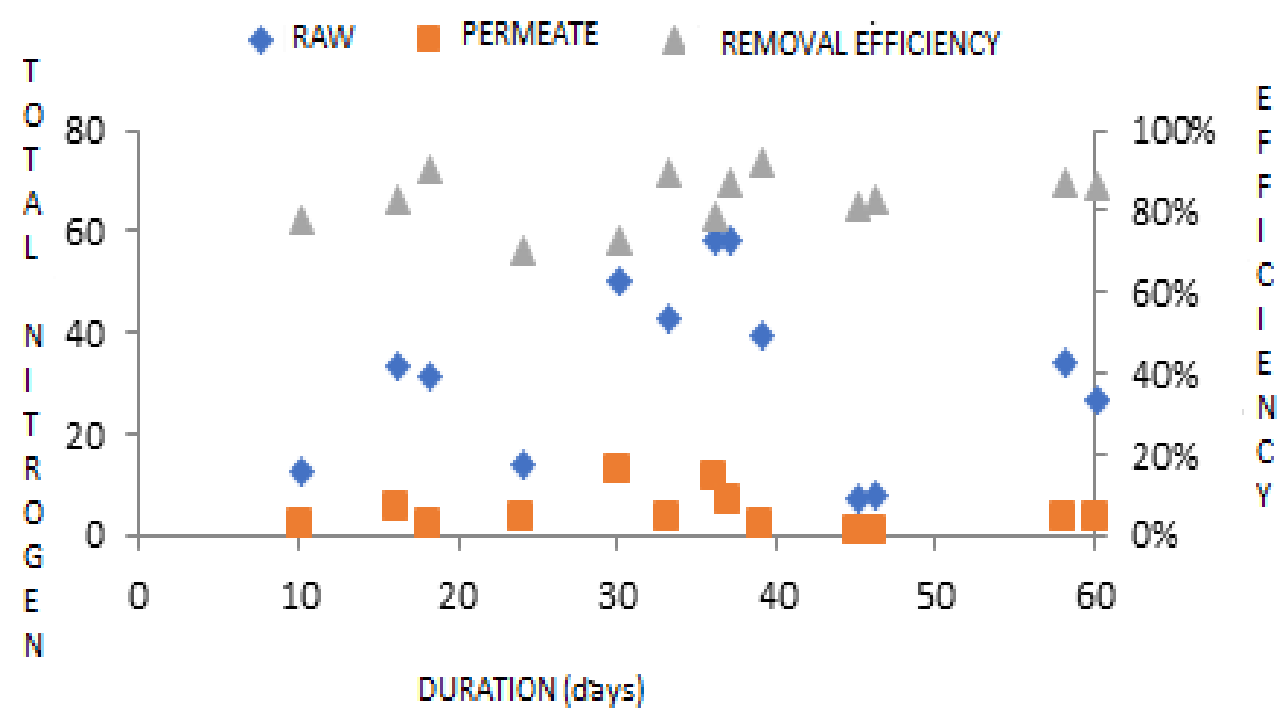

Figure 5. Nitrogen removal by the MBR treating mall sewage.

We did not use the anoxic cycles to improve denitrification. Thus, we observed the average concentration of nitrites and nitrates of $1.65 \mathrm{mg} \mathrm{L}^{-1}$ and $4.64 \mathrm{mg} \mathrm{L}^{-1}$, respectively, but the average removal of ammonium was $80.7 \%$. Several factors are important to nitrogen removal, but we highlighted three. A) age of sludge: Bani-Melhem et al. (2015) operated a MBR for 42 days with total retention of the sludge; the system removed $88 \%$ of nitrogen. The authors reported that nitrifying bacteria requires more time to nitrify the ammonia. Likewise, Capodici et al. (2015) reported that an age of sludge of only 5 days limited the growth of nitrifying bacteria. B) Dissolved oxygen: Chen et al. (2012) attributed low ammonia removal in MBR to low oxygen supplied to the system. C) Anoxic cycle: Belli et al. (2014) reported the removal of ammonia of $99 \%$ and total nitrogen of $82 \%$ when an MBR was operated in a sequential batch. Barbosa et al. (2016) established nitrification and simultaneous denitrification (NDS) conditions, removing both COD and total nitrogen in a single reactor. However, we kept the age of the sludge at 30 days and the dissolved oxygen above $2 \mathrm{mg} \mathrm{L}^{-1}$. The presence of nitrites in the effluent of the MBR shows that there was nitrification, but denitrification requires the introduction of the anoxic cycle. However, we did not insert the anoxic cycle in our work, and 
thus we identified nitrites in the treated effluent, although the concentration is low.

The average permeate flux and suspended solids of the MBR are presented in Figure 6. We observed an inverse relationship between both parameters: the higher the TSS in the reactor, the lower the permeate flux. The average permeate flux was $7.00 \pm 1.84 \mathrm{~L} \mathrm{~h}^{-1} \mathrm{~m}^{-2}$. In fact, we can expect high permeate flux in the operation of MBR for the treatment of wastewater due to the high concentration of suspended solids. The literature also shows low permeate flux in the operation of the MBR for the treatment of different wastewater $\left(6.74 \mathrm{~L} \mathrm{~h}^{-1} \mathrm{~m}^{-2}\right)$. Kellner (2014) used a MBR with submerged hollow fiber membrane for the treatment of sanitary effluents with SST ranging from $3,000 \mathrm{mg} \mathrm{L}^{-1}$ to $5,000 \mathrm{mg} \mathrm{L}^{-1}$ and the permeate flux was $6.74 \mathrm{~L} \mathrm{~h}^{-1} \mathrm{~m}^{-2}$. Huelgas and Funamizu (2010) observed a permeate flux of $9 \mathrm{~L} \mathrm{~h}^{-1} \mathrm{~m}^{-2}$ for wastewater treatment of washing machines and kitchen sinks, suggesting that the high concentration of suspended solids in the bioreactors and the established operating conditions make it impossible to obtain high flows through the membranes. Bani-Melhem et al. (2015) reported that the high concentration of TSS in MBR, higher COD concentrations and inorganic impurities in the raw sewage can have a significant impact on the reduction of flow. In fact, we used the raw sewage from the mall without any treatment, and thus inorganic impurities can impact permeate flux.

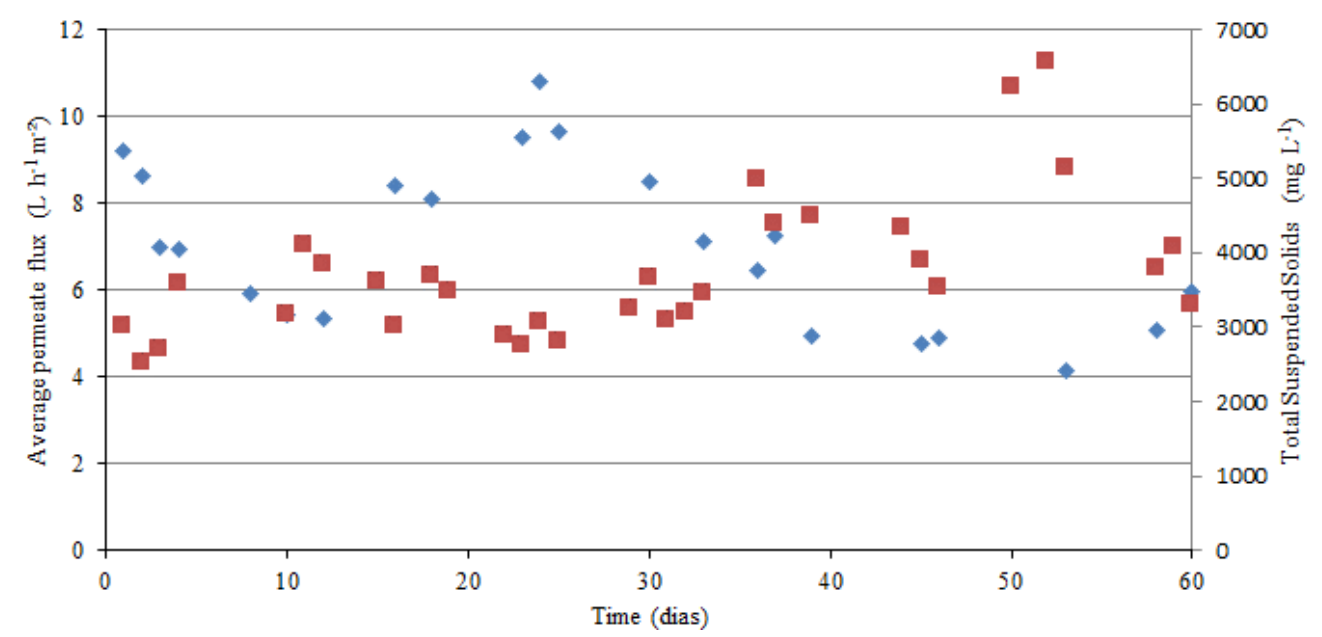

Figure 6. Average permeate flux and total suspended solids in the MBR.

The permeate flux of the MBR over a $24 \mathrm{~h}$ period with a $4 \mathrm{~h}$ filtration cycle and 30 second back flushes with a constant pressure of $40 \mathrm{kPa}$ is shown in Figure 7.

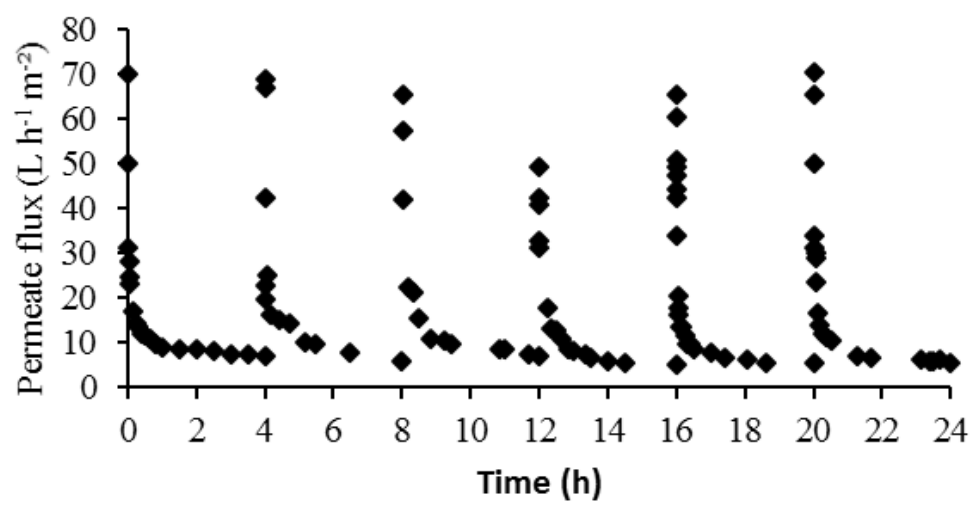

Figure 7. Permeate flux of the MBR in the treatment of mall wastewater during a $24 \mathrm{~h}$ period.

The permeate flux of the MBR presented a strong reduction in the first minutes of operation and a smooth reduction in the later period, achieving some stability in the range of $5 \mathrm{~L} \mathrm{~h}^{-1} \mathrm{~m}^{-2}$ 
to $10 \mathrm{~L} \mathrm{~h}^{-1} \mathrm{~m}^{-2}$. After the back flushes, the permeate was recovered, reaching $60 \mathrm{~L} \mathrm{~h}^{-1} \mathrm{~m}^{-2}-70 \mathrm{~L}$ $\mathrm{h}^{-1} \mathrm{~m}^{-2}$. The recovery of the initial permeate flux indicates that pore clogging of the membrane was fully reversible. The low resistance of pore clogging was also observed by Zhang et al. (2014), as they identified that fouling is the major filtration resistance. Belli et al. (2014) studied an MBR for nutrient removal from municipal sewage and identified the presence of polysaccharides and proteins (major agents of fouling in MBR) in the reactor. In fact, exopolysaccharides (EPS) are mainly responsible for fouling in the MBR (Drews et al., 2006). However, in our experiments we can recover the permeate over the 60 days without any chemical cleaning. Melin et al. (2006) suggest the installation of preliminary MBR treatments to reduce membrane fouling and extend the cycle of operation.

Finally, camparing the MBR with conventional activated sludge, Hao et al. (2018) developed a method to measure the benefits with regard to the sustainability and economic viability of both processes. In contrast to previous studies, the indexes created by Hao et al. (2018) showed that the MBR is not a more sustainable process when compared to conventional activated sludge. We disagree, due to the simple fact that the quality of effluent of MBR will be higher than the effluent from conventional activated sludge. In the course of time, the MBR will also be economically competitive.

\section{CONCLUSIONS}

The MBR system is an alternative with great potential for application in the treatment of sewage from malls and establishments generating effluents with high organic load.

The system presented great removal of color and turbidity, reaching average efficiency of $91.20 \%$ and $97.20 \%$, respectively. The COD and BOD removal was $89 \%$ and $87 \%$, respectively. Furthermore, the permeate quality was stable, even with variations in the organic load of the raw wastewater.

The MBR, despite the fact that we did not use the anoxic cycle, removed nutrients with good performance. The average removal of phosphorus reached was $49 \%$ and total nitrogen removal was $84 \%$. The nitrification process was influenced by the age of the sludge maintained at 30 days and the amount of oxygen supplied to the bioreactor. The introduction of an anoxic phase into the MBR operating cycle could provide simultaneous nitrification and denitrification processes.

The MBR presented an average permeate of $7.00 \mathrm{~L} \mathrm{~h}^{-1} \mathrm{~m}^{-2}$, with the oscillations related mainly to the variation of biomass concentration in the bioreactor. Despite a strong drop of permeate flux in the initial minutes, membrane fouling was reversible and was controlled by backflushes.

\section{REFERENCES}

APHA; AWWA; WEF. Standard Methods for the Examination of Water and Wastewater. 21. ed. Washington, 2005.

BANI-MELHEM, K.; AL-QODAHB, Z.; AL-SHANNAGC, M.; A QASAIMEHD, A.; QTAISHATC, M. R.; ALKASRAWI, M. On the performance of real grey water treatment using a submerged membrane bioreactor system. Journal of Membrane Science, v. 476, p. 40-49, 2015. https://doi.org/10.1016/j.memsci.2014.11.010

BARBOSA, I. M.; MIERZWA, J. C.; HESPANHOL, I.; SUBTIL, E. L. Remoção de matéria orgânica e nitrogênio em biorreator com membranas submersas operando em condição de nitrificação e desnitrificação simultâneas. Revista Ambiente \& Água, v. 11, n. 2, p. 304-315, 2016. http://dx.doi.org/10.4136/ambi-agua.1684 
BELLI, T. J.; BERNARDELLI, J. K. B.; AMARAL, P. A. P.; COSTA, R. E.; AMARAL, M. C. S.; LAPOLLI, F. R. Biological nutrient removal in a sequencing batch membrane bioreactor treating municipal wastewater. Desalination and Water Treatment, p. 1-8, 2014. https://doi.org/10.1080/19443994.2014.952961

CAPODICI, M.; DI BELLA, G.; DI TRAPANI, D.; TORREGROSSA, M. Case study: pilot scale experiment with MBR operated in intermittent aeration condition: analysis of biological performance. Bioresource Technology, v. 177, p. 398-405, 2015. https://doi.org/10.1016/j.biortech.2014.11.075

CHEN, W.; LIU, J.; XIE, F. Identification of the moderate SRT for reliable operation in MBR. Desalination, v. 286, p. 263-267, 2012. https://doi.org/10.1016/j.desal.2011.11.033

DREWS, A.; LEE, C.H.; KRAUME, M. Membrane fouling: A review on the role of EPS. Desalination, v. 200, p. 186-188, 2006. http://dx.doi.org/10.1016/j.desal.2006.03.290

HAN, S. S.; BAE, T. H.; JANG, G. G.; TAK, T. M. Influence of sludge retention time on membrane fouling and bioactivities in membrane bioreactor system sp. Process Biochemistry, n. 40, p. 2393-2400, 2005. https://doi.org/10.1016/j.procbio.2004.09.017

HAO, X.D.; LIA, J.; van LOOSDRECHT, M. C. M.; LIA, T.Y. A sustainability-based evaluation of membrane bioreactors over conventional activated sludge processes. Journal of Environmental Chemical Engineering, v. 6, p. 2597-2605, 2018. https://doi.org/10.1016/j.jece.2018.03.050

HUANG, L.; LEE, D. J. Membrane bioreactor: A mini review on recent R\&D Works sp. $\begin{array}{llllll}\text { Bioresource } & \text { Technology, } & \text { v. } & 194, & \text { p. } & 383-388,\end{array}$ https://doi.org/10.1016/j.biortech.2015.07.013

HUELGAS, A.; FUNAMIZU, N. Flat-plate submerged membrane bioreactor for the treatment of higher-load greywater. Desalination, v. 250, n. 1, p. 162-166, 2010. https://doi.org/10.1016/j.desal.2009.05.007

KELLNER, R. L. Biorreator à membrana de leito móvel em bateladas sequenciais para a remoção de nutrientes e matéria orgânica de efluentes sanitários 2014. 146 f. Dissertação (Mestrado em Engenharia Sanitária e Ambiental) - Universidade Federal de Santa Catarina, Florianópolis, 2014.

KESKES, S.; HMAIE, F.; GANNOUN, H.; BOUALLAGUI, H.; GODON, J. J.; HAMDI, M. Performance of a submerged membrane bioreactor for the aerobic treatment of abattoir wastewater. Bioresource Technology, n. 103, p. 28-34, 2012. https://doi.org/10.1016/j.biortech.2011.09.063

KOMESLI, O. T.; MUZ, M.; AK, S.; GÖKÇAY, C. F. Prolonged reuse of domestic wastewater after membrane bioreactor treatment. Desalination and Water Treatment, n. 53, p. 3295-3302, 2015. https://doi.org/10.1080/19443994.2014.934107

KRZEMINSKI, P.; LEVERETTE, L.; MALAMIS, S.; KATSOU, E. Membrane bioreactors. A review on recent developments in energy reduction, fouling control, novel configurations, LCA and market prospects. Journal of Membrane Science, v. 527, p. 207-227, 2017. https://doi.org/10.1016/j.memsci.2016.12.010

MAESTRI, R. S. Biorreator à membrana como alternativa para o tratamento de esgotos anitários e reuso da água. 2007. 101 f. Dissertação (Mestrado em Engenharia Ambiental) - Universidade Federal de Santa Catarina, Florianópolis. 2007. 
MAQBOOL, T.; KHAN, S. J.; LEE, C. H. Effects of filtration modes on membrane fouling behavior and treatment in submerged membrane bioreactor. Bioresource Technology, v. 172, p. 391-395, 2014. https://doi.org/10.1016/j.biortech.2014.09.064

MELIN, T.; JEFFERSON, B.; BIXIO, D.; THOEYE, C.; DE WILDE, W.; DE KONING, J.; VAN DER GRAAF, J.; WINTGENS, T. Membrane bioreactor technology for wastewater treatment and reuse. Desalination, v. 187, p. 271-282, 2006. https://doi.org/10.1016/j.desal.2005.04.086

NEOH, C. H.; NOOR, Z. Z.; MUTAMIM, N. S. A.; LIM, C. K. Green technology in wastewater treatment technologies: Integration of membrane bioreactor with various wastewater treatment systems. Chemical Engineering Journal, v. 283, p. 582-594, 2016. https://doi.org/10.1016/j.cej.2015.07.060

NGUYEN, T. T; BUI, X. T; VO, T. D. H; NGUYEN, D. D.; NGUYEN, P. D; DO H. L. C; NGO, H. H; GUO, W. Performance and membrane fouling of two types of laboratoryscale submerged membrane bioreactors for hospital wastewater treatment at low flux condition sp. Separation and Purification Technology, v. 165, p. 123-129, 2016. https://doi.org/10.1016/j.seppur.2016.03.051

PRANEETH, K.; MOULIK, S.; VADTHYA, P.; BHARGAVA, S. K. Performance assessment and hydrodynamic analysis of a submerged membrane bioreactor for treating dairy industrial effluent. Journal of Hazardous Materials, v. 274, p. 300-313, 2014. https://doi.org/10.1016/j.jhazmat.2014.04.030

RODRÍGUEZ-HERNÁNDEZ, L.; ESTEBANGARCÍA, A. L.; TEJERO, I. Comparison between a fixed bed hybrid membrane bioreactor and a conventional membrane bioreactor for municipal wastewater treatment: a pilot scale study. Bioresource Technology, v. 152, p. 212-219, 2014. https://doi.org/10.1016/j.biortech.2013.10.081

SUBTIL, E. L.; HESPANHOL, I.; MIERZWA, J. C. Biorreatores com membranas submersas (BRMs): alternativa promissora para o tratamento de esgotos sanitários para reuso sp. Revista Ambiente \& Água, v. 8, n. 3, 2013. https://doi.org/10.4136/ambi-agua.1230

SUBTIL, E. L.; HESPANHOL, I.; MIERZWA, J. C. Comparison between a conventional membrane bioreactor (C-MBR) and a biofilm membrane bioreactor (BF-MBR) for domestic wastewater treatment. Brazilian Journal of Chemical Engineering, v. 31, n. 3, p. 683 - 691, 2014. https://doi.org/10.1590/0104-6632.20140313s00002890

VILLAIN, M.; MARROT, B. Influence of sludge retention time at constant food to microorganism ratio on membrane bioreactor performances under stable and unstable state conditions. Bioresource Technology, n. 128, p. 134-144, 2013. https://doi.org/10.1016/j.biortech.2012.10.108

ZHANG, Y.; ZHANG, M.; WANG, F.; HONG, H.; WANG, A.; WENG, X.; LIN, H. Membrane fouling in a submerged membrane bioreactor: Effect of $\mathrm{pH}$ and its implications. Bioresource Technology, v. 152, p. 7-14, 2014. https://doi.org/10.1016/j.biortech.2013.10.096 